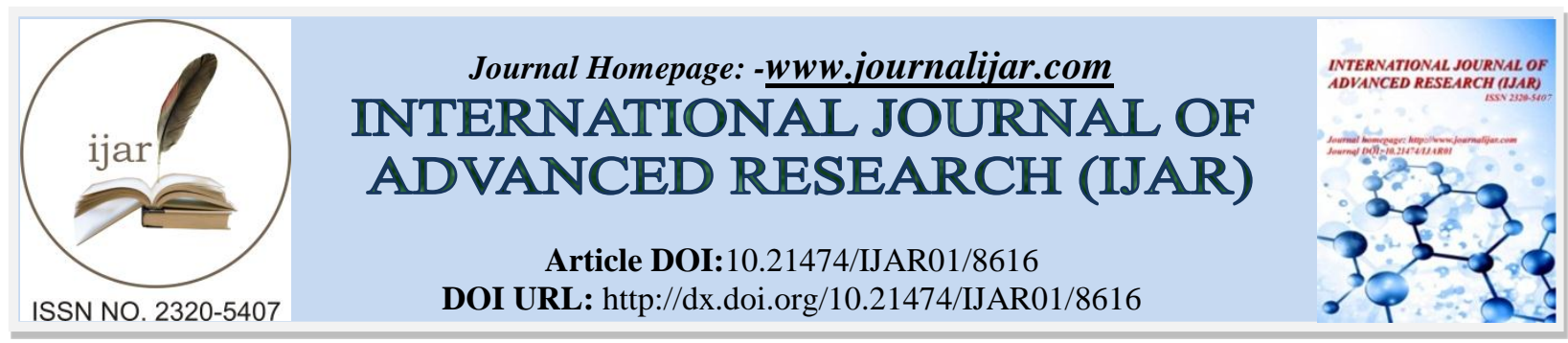

RESEARCH ARTICLE

\title{
POTENTIAL EFFECT OF PROPOLIS AS AN INTRACANAL MEDICAMENT ON ROOT CANAL DISINFECTION AND DENTIN MICROHARDNESS: (AN IN VITRO STUDY).
}

\section{Hossam Eldin Ahmed Shaheen ${ }^{1}$, AmrAhmed Bayoumi ${ }^{2}$ and Hossam Mohamed Essam Eldin Tawfik ${ }^{3}$.}

1. Masters of science, Misr International University, Cairo, Egypt.

2. Lecturer of Endodontics, Misr International University.

3. Professor of Endodontics, Misr International Universty.

\section{Manuscript Info}

\section{Manuscript History}

Received: 05 January 2018

Final Accepted: 07 February 2019

Published: March 2019

\begin{abstract}
The study aimed to evaluate the potential effect of three intracanal medicaments namely propolis, Calcium hydroxide and Chlorhexidine gel on the root canal disinfection. Materials and method: Sixty-Four samples were chosen for this study. They were divided into four groups, group I received no medication, group II received propolis, group III received Calcium Hydroxide and group IV received Chlorhexidine. The four groups were subdivided into two subgroups A and $\mathrm{B}$, with two-time intervals 1 and 2 weeks. For bacterial evaluation the samples were inoculated with Enterococcus Faecalis. Paper points were placed inside infected root canals and placed in a test tube for CFU count. Results: Results showed that propolis had an intermediate effect on Enterococcus faecalis due to the presence of phenolic compounds in propolis which can eliminated bacteria inside root canal. Calcium hydroxide showed an intermediate effect against bacteria due to its high alkalinity that also can eliminate bacteria. Chlorhexidine showed the highest effect against bacteria due to its ability to stay active inside canal for a long time (substantivity). These results were similar for the 2 time periods. Conclusion: Both Propolis and $\mathrm{Ca}(\mathrm{OH}) 2$ showed moderate action on intracanal microbes over the two time periods and CHX can be regarded as the best intracanal medicaments regarding its action on intracanal microbes.
\end{abstract}

Copy Right, IJAR, 2019,. All rights reserved.

\section{Introduction:-}

The main goal of endodontic treatment is to eliminate the bacteria inside the root canal. Bacterial elimination is done using mechanical preparation of the canal using endodontic instruments, however mechanical preparation alone is not effective in eliminating the bacteria inside the canal (1). Hence the use of chemical materials to eliminate bacteria is essential in endodontic treatment. Chemical treatment includes the use of irrigating solutions and intracanal medicaments. The combination of chemo-mechanical preparation ensures the eradication of bacteria inside root canal and ensures the success of the endodontic treatment. $(2,3)$

For many years the use of intracanal medicaments has been advocated to enhance the success rates of root canal treatment. Phenolic compounds are used for their potent antibacterial activity; however, they are found to be very 
toxic and irritant to soft tissues(4). Calcium hydroxide has been used for its antibacterial activity, but they are found not to be effective against all types of bacteria. So, the search for other materials is done to improve the effect of intracanal medicaments against bacteria. $(5,6,7)$

Ancient Egyptians and Greeks used natural materials in medicine(8). Among these natural materials used nowadays showing great expectations is propolis. Propolis is a honeybee product that is extracted in order to protect beehives. Propolis is used in dentistry because of its biological properties. These properties are attributed to components of propolis, which are 30\% wax, 50\% resin and vegetable balsam, 10\% essential and aromatic oils, and 5\% pollen and other substances. The main component of propolis is phenolic compounds, which contain flavonoids; these compounds give propolis its biological properties. Flavonoids give propolis its main antibacterial action. Among other properties of propolis are antiviral, antifungal, anti-inflammatory, and antioxidant $(7,8,9,10)$. Propolis is found to be very useful in dentistry as an antibacterial agent in intracanal medications and irrigation solutions, also as a pulp capping agent, and in treatment of dentinal hypersensitivity $(8,11)$. Propolis is mainly effective against grampositive bacteria(4). So, its use in endodontic treatment is of great importance especially against Enterococcus faecalis $(1,3,12,13)$.

\section{Materials and Methods:- Materials: \\ Propolis, Calcium Hydroxide, Chlorhexidine, ProTaper Universal Files and Enterococcus faecalis}

\section{Methods:}

Sixty-four human extracted single rooted free from caries, cracks or fractures were selected. All teeth were placed in $2.5 \% \mathrm{NaOCL}$ for 1 hour and scaled and cleaned from any calculus or debris on its external surface using an ultrasonic scaler and then stored in a saline solution. Teeth were decoronated using safe sided diamond disc under water coolant to obtain a 16-mm root segment. Root canals were enlarged using Rotary NiTi files (Dentsply Sirona ProTaper universal) with saline solution as an irrigant between each file and a $\mathrm{k}$ file \#15 was used to ensure canal patency after each instrument. The orifices of each tooth were opened using a SX file. Cleaning and shaping were done until file \# F5 finishing the apical preparation at size 50 and taper 0.05 . The speed used was $250 \mathrm{rpm}$ and the torque used was $2.0 \mathrm{~N} / \mathrm{cm} 2$ according to manufacturer's instructions. Apices of the teeth were sealed using composite restoration.

The sixty-four samples were randomly divided equally into four groups each group with sixteen teeth each. Group 1 received no medication only mechanical preparation and saline irrigation was done and served as a control group, Group 2 received propolis, Group 3 received Calcium Hydroxide and Group 4 received Chlorhexidine gel. Each group was subdivided into 2 subgroups according to the period of canal dressing each containing 8 samples, Subgroup A for one week and Subgroup B for two weeks.

All samples were sterilized by wrapping them in moist gauze and running them through an autoclave cycle. A clinical isolate of E. faecalis from the Microbiology laboratory (Central laboratories, Ministry of Health, Egypt) was used for biofilm formation. The bacterial strain was inoculated in Brain Heart Infusion broth (BHI; Difco Laboratories, Detroit, MI, USA) and incubated at $37^{\circ} \mathrm{C}$ for 24 hours. The experimental suspensions were prepared by cultivating the biological marker on the surface of Brain Heart Infusion agar (BHIA; Difco Laboratories) following the same incubation conditions. The bacterial cells were resuspended in saline to reach a final concentration of about 3 x 108 cells/mL, adjusted to No. 1 MacFarland turbidity standard which was used to infect the samples.

The propolis was measured using a sensitive scale. The mix was made fresh in the lab by mixing the propolis powder to glycerin and the ratio was $0.0749 \mathrm{gm}$ to 1 drop of liquid. Then the fresh mix was placed inside a plastic syringe to be injected inside canal. Calcium hydroxide (META BIOMED) and Chlorhexidine (EZ-Pac Dental Materials) were placed in canal using a syringe. Medications were overfilled to ensure canal to be filled completely. Then temporary filling material (Coltosol F) was used to seal the roots coronally (Coltene Whaledent). During $1^{\text {st }}$ week medicaments were applied in infected root canals as assigned to each group (Figure 1). The samples were placed again in saline solution and placed in incubator for one week (subgroups A\&B). The cycle was repeated again during the $2^{\text {nd }}$ week (samples of subgroup B)

All root canals were flushed with saline solution to remove dressing medicaments then two paper point \# 30 was 
placed in each canal and then placed in a test tube one for each tooth. Agar plates were then cultivated with the bacteria and incubated for 48 hours. Colony forming units (CFU) was counted for samples of each group and subgroup. Visible colonies of E. faecalis were counted in every plate and the number of colonies/plates was multiplied by the corresponding dilution factor and by 10 to determine the total colony forming units (CFU) per ml of sample (Figure 2).

\section{Results:-}

At one-week period, the number of micro-organisms was at its highest value for the samples medicated by saline. The samples medicated by propolis and $\mathrm{Ca}(\mathrm{OH}) 2$ were intermediate. While samples medicated by $\mathrm{CHX}$ showed the lowest number of microbes. At two weeks period, the number of micro-organisms was at its highest value for the samples medicated by saline. The samples medicated by propolis and $\mathrm{Ca}(\mathrm{OH}) 2$ were intermediate. While samples medicated by CHX showed the lowest number of microbes (Table 1).

Statistical analysis showed either after 1 week or 2 weeks, there was a statistically significant difference between the groups. Pair-wise comparisons revealed that Saline showed the statistically significantly highest mean $\log _{10}$ CFU counts. There was no statistically significant difference between Propolis and $\mathrm{Ca}(\mathrm{OH}) 2$; both showed statistically significantly lower mean $\log _{10}$ CFU counts. CHX showed the statistically significantly lowest mean $\log _{10}$ CFU counts. (Table 2,3) (Figure 3,4).

As regards saline group, there was no statistically significant change in mean $\log 10 \mathrm{CFU}$ counts after 2 weeks. While for Propolis, $\mathrm{Ca}(\mathrm{OH}) 2$ and $\mathrm{CHX}$ groups, there was statistically significant decrease in mean Log $10 \mathrm{CFU}$ counts after 2 weeks (Table 4) (Figure 5).

The percentage reduction in counts was calculated as: Bacterial counts (2 weeks) - Counts (1 week) / Counts 1 week) $\mathrm{x} 100$. There was a statistically significant difference between the groups. Pair-wise comparisons reveled that CHX showed the statistically significantly highest mean percentage reduction in bacterial counts $(51.8 \%)$. There was no statistically significant difference between Propolis and $\mathrm{Ca}(\mathrm{OH}) 2$; both showed statistically significantly lower mean percentage reduction (21.4\% and $17.9 \%$ respectively). Saline showed the statistically significantly lowest mean percentage reduction in bacterial counts $(0.43 \%)$ (Table 5) (Figure 6).

\section{Discussion:-}

Bacteria can harbor areas which are inaccessible by intra radicular instruments. Chemical agents are therefore mandatory for proper root canal cleaning and shaping. Intracanal medicaments are regarded as an integral part of canal disinfection. Most commonly used medicament are calcium hydroxide and Chlorohexidine $(1,2,3,5,7,14,15,16,17,18,19,20,21,22,23)$.

Recently the use of natural materials as medicaments have been advocated. aromatic aldehydes and alcohols, fatty acids, stilbenes, and $\beta$-steroids. The use of propolis as a root canal medicament have been suggested $(1,4,7,8,9,10,11,12,13)$. The aim of the present study is to test the antibacterial effect of propolis and to compare it with bench mark materials as $\mathrm{Ca}(\mathrm{OH}) 2$ and $\mathrm{CHX}$.

E. faecalis was the bacteria of choice because it was found to be the most resistant bacteria that can harbor inaccessible places in canal and it caused failure in endodontic treatment cases. E. faecalis can survive in very harsh environments whether in the presence or absence of oxygen or in high alkaline Ph levels. They can invade the dentinal tubules and can survive without the help of any nutrients or any other bacteria. E. faecalis has been shown to adhere to host cells, express proteins that allow it to compete with other bacterial cells and alter host responses. It exhibits antibiotic resistance of genes from other microbes or by spontaneous mutation thereby making these microbes recalcitrant to the usual root canal treatments $(1,4,12,13,24,25,26,27)$.

Colony Forming Units was the method in this study chosen because of its easiness, simplicity, accuracy and standardization. It has the advantage of being able to count any number of bacteria whether it is too many or too few and has the other advantage of being able to count only the viable bacteria and eliminating the dead ones $(28,29,30)$. The results of the antibacterial counts showed that the samples treated with CHX at 1st week period showed the highest reduction values in bacterial count. In the 2nd week period groups CHX showed significant reduction in bacterial count than 1st week period. This is attributed to the fact that CHX has a strong antibacterial effect. CHX 
has a wide range of activity against both Gram positive and negative bacteria. CHX has antibacterial substantivity for up to 12 weeks $(1,3,7,13,14,18,19,20,21,22)$.

Sample treated with $\mathrm{Ca}(\mathrm{OH}) 2$ showed intermediate results in their effectiveness against bacteria. In the 1st week period there was no significant difference in regard to bacterial reduction. There was a significant difference in reduction of bacteria in the 2 nd week period. This is because $\mathrm{Ca}(\mathrm{OH}) 2$ has a very high $\mathrm{pH}$ (up 12.5). This $\mathrm{pH}$ if maintained, the effect of $\mathrm{Ca}(\mathrm{OH}) 2$ will remain for a long a time. However, in several studies it was found that $\mathrm{Ca}(\mathrm{OH}) 2$ was found to be ineffective against E. Faecalis, this why the results of the present study showed intermediate results and were less than $\operatorname{CHX}(1,5,6,7,14,15,16,17,18,19,20)$.

Regarding propolis at the 1st week period, it was found to have intermediate action against bacteria inside canal, similar to that of $\mathrm{Ca}(\mathrm{OH}) 2$ and there was a significant difference in bacterial reduction in the 2nd week period. Propolis has been used by humans in health and food preservation, but recently in the last years the interest has grown due to its broad spectrum of biological and pharmacological properties.

This study was aiming to for the search for an ideal intracanal medicament regarding its antibacterial action. The comparison of propolis to standard medicaments showed its moderate action against bacteria. Further studies can help enhance our final product that can improve its desirable characteristics.

\section{Conclusion:-}

Based on the results of the present study the following conclusions could be drawn:

1. Both of Propolis and $\mathrm{Ca}(\mathrm{OH})_{2}$ showed moderate action on intracanal microbes over the two time periods.

2. CHX can be regarded as the best intracanal medicaments regarding its action on intracanal microbes.

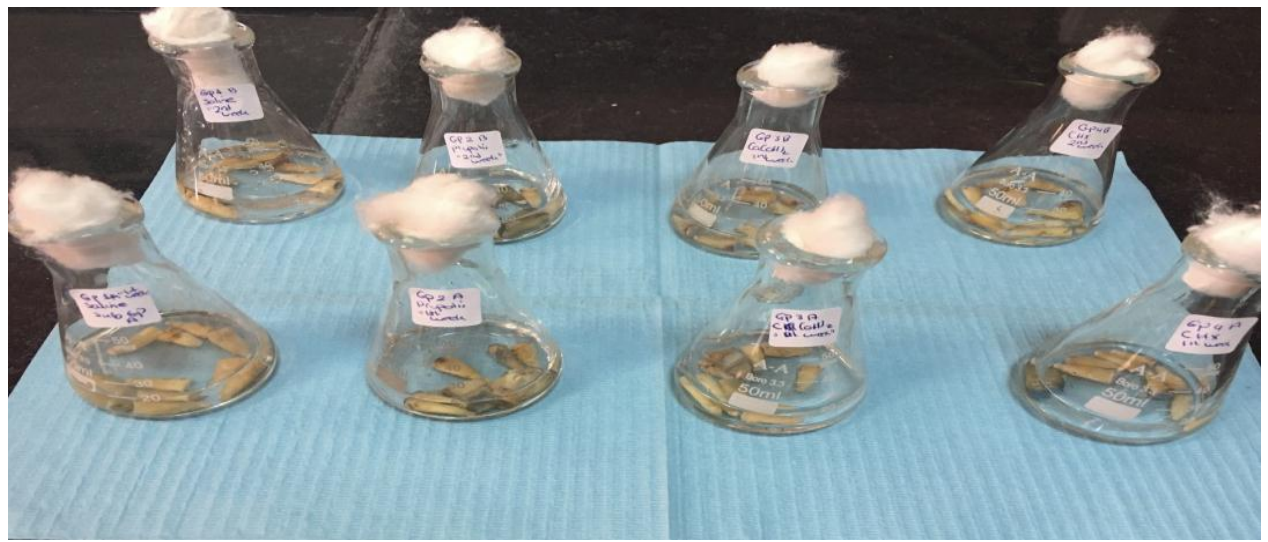

Figure 1:-showing sample grouping after medication placement.

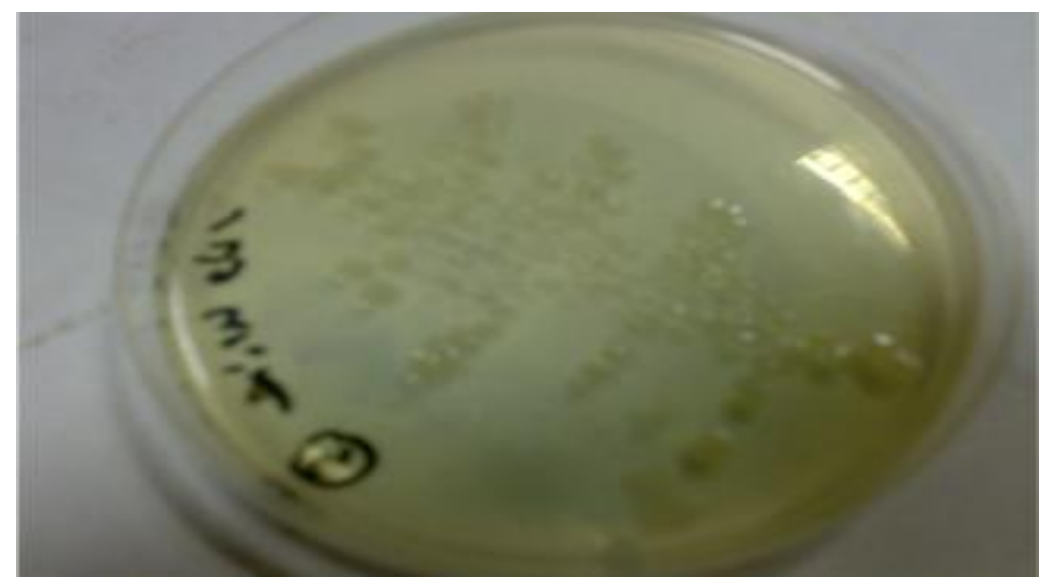

Figure 2:-showing bacterial culture on agar plate 


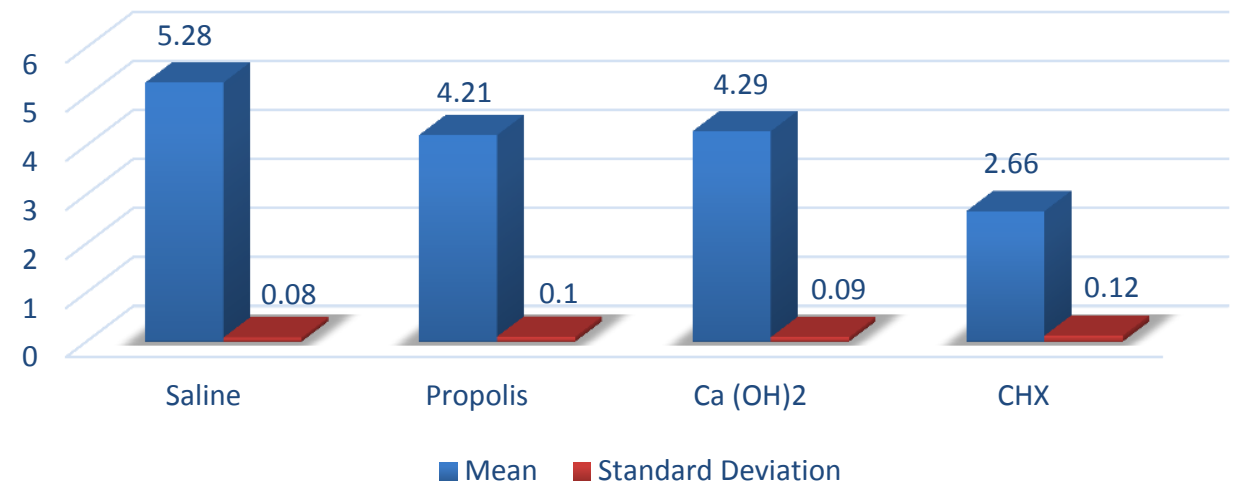

Figure 3:-Bar chart representing mean and standard deviation values for $\log _{10}$ CFU counts in the different groups after 1 week

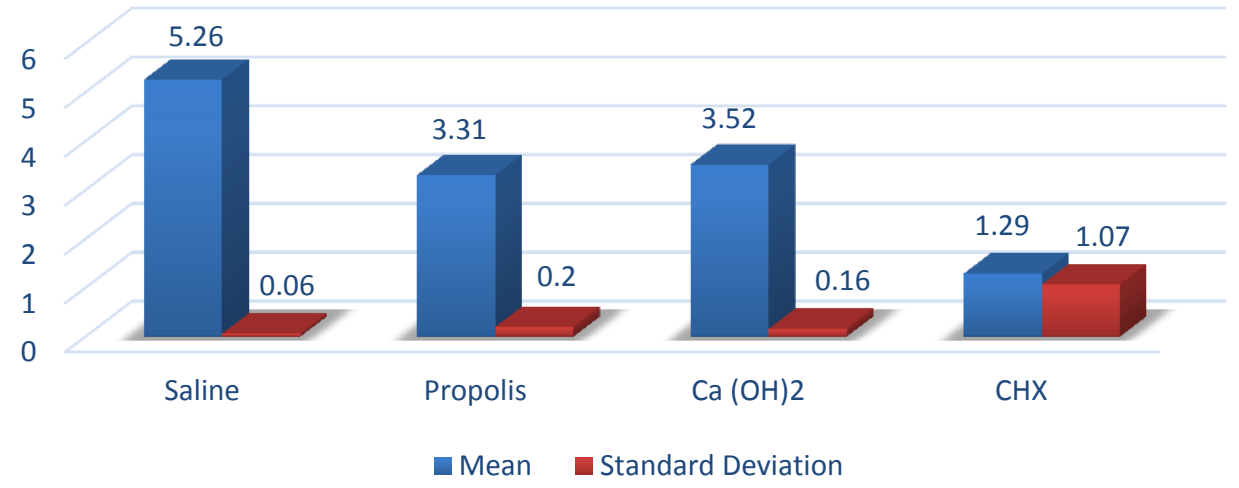

Figure 4:-Bar chart representing mean and standard deviation values for $\log _{10} \mathrm{CFU}$ counts in the different groups after 2 weeks

Figure 5:-Bar chart representing mean and standard deviation values

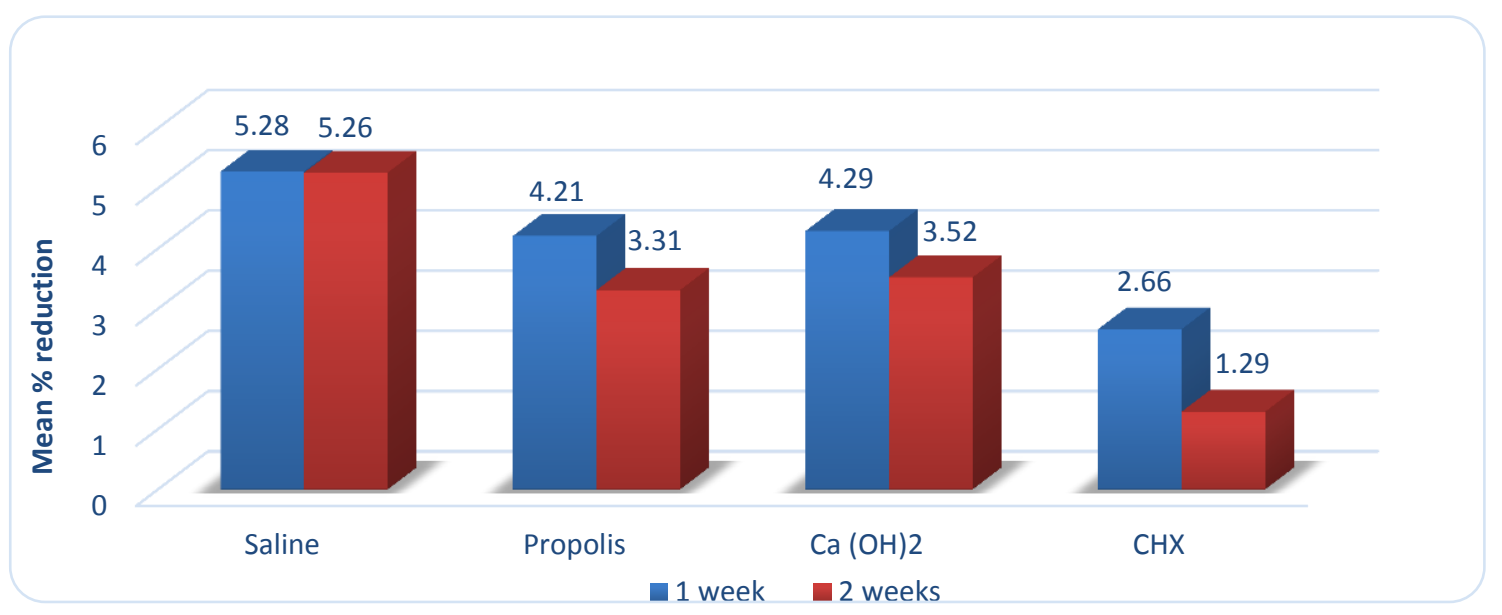




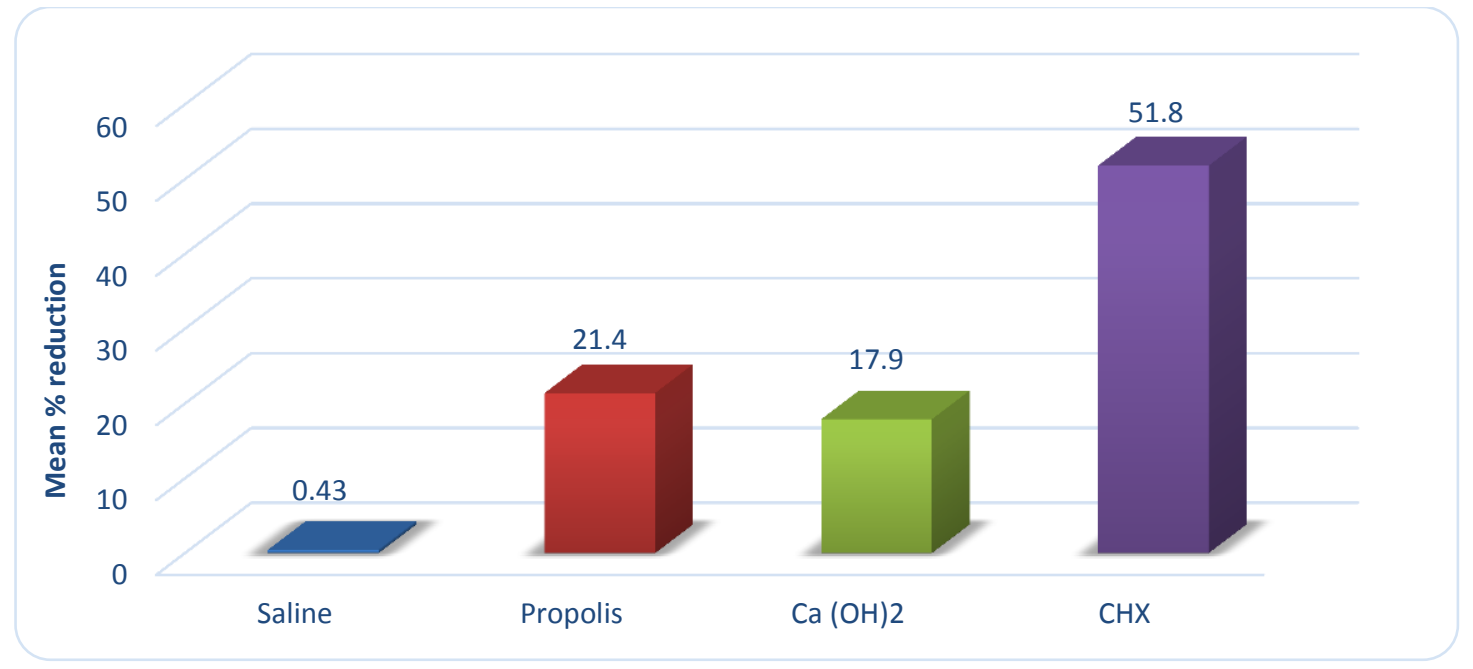

Figure 6:-Bar chart representing mean and standard deviation values for percentage reduction in bacterial counts in the different groups

Table 1:-Descriptive statistics for $\log _{10}$ CFU counts of different groups

\begin{tabular}{|c|c|c|c|c|c|c|c|c|}
\hline \multirow[t]{2}{*}{ Time } & \multirow[t]{2}{*}{ Group } & \multirow[t]{2}{*}{ Mean } & \multirow[t]{2}{*}{ SD } & \multirow[t]{2}{*}{ Median } & \multirow[t]{2}{*}{ Minimum } & \multirow[t]{2}{*}{ Maximum } & \multicolumn{2}{|c|}{$95 \% \mathrm{CI}$} \\
\hline & & & & & & & $\begin{array}{l}\text { Lower } \\
\text { bound }\end{array}$ & $\begin{array}{l}\text { Upper } \\
\text { bound }\end{array}$ \\
\hline \multirow[t]{4}{*}{1 week } & Saline & 5.28 & 0.08 & 5.30 & 5.18 & 5.40 & 5.22 & 5.35 \\
\hline & Propolis & 4.21 & 0.10 & 4.22 & 4.00 & 4.30 & 4.12 & 4.29 \\
\hline & $\mathrm{Ca}(\mathrm{OH}) 2$ & 4.29 & 0.09 & 4.30 & 4.18 & 4.48 & 4.21 & 4.37 \\
\hline & CHX & 2.66 & 0.12 & 2.65 & 2.48 & 2.90 & 2.56 & 2.76 \\
\hline \multirow[t]{4}{*}{2 weeks } & Saline & 5.26 & 0.06 & 5.26 & 5.18 & 5.34 & 5.21 & 5.30 \\
\hline & Propolis & 3.31 & 0.20 & 3.28 & 3.08 & 3.60 & 3.14 & 3.47 \\
\hline & $\mathrm{Ca}(\mathrm{OH}) 2$ & 3.52 & 0.16 & 3.54 & 3.30 & 3.70 & 3.39 & 3.65 \\
\hline & CHX & 1.29 & 1.07 & 2.00 & 0.00 & 2.30 & 0.39 & 2.18 \\
\hline
\end{tabular}

Table 2:-Descriptive statistics and results of Kruskal-Wallis test for comparison between $\log _{10}$ CFU counts of different groups after 1 week

\begin{tabular}{|l|c|c|c|}
\hline Group & Mean & SD & $P$-value \\
\hline Saline & $5.28^{\mathrm{A}}$ & 0.08 & \multirow{2}{*}{$<0.001^{*}$} \\
\hline Propolis & $4.21^{\mathrm{B}}$ & 0.10 & \multirow{2}{*}{} \\
\hline $\mathrm{Ca}(\mathrm{OH}) 2$ & $4.29^{\mathrm{B}}$ & 0.09 \\
\hline $\mathrm{CHX}$ & $2.66^{\mathrm{C}}$ & 0.12 & \\
\hline
\end{tabular}

*: Significant at $\mathrm{P} \leq 0.05$, Different superscripts in the same column are statistically significantly different

Table 3:-Descriptive statistics and results of Kruskal-Wallis test for comparison between $\log _{10}$ CFU counts of different groups after 2 weeks

\begin{tabular}{|l|c|c|c|}
\hline Group & Mean & SD & $P$-value \\
\cline { 1 - 3 } Saline & $5.26^{\mathrm{A}}$ & 0.06 & \multirow{2}{*}{$<0.001^{*}$} \\
\hline Propolis & $3.31^{\mathrm{B}}$ & 0.20 & \multirow{2}{*}{} \\
\hline $\mathrm{Ca}(\mathrm{OH}) 2$ & $3.52^{\mathrm{B}}$ & 0.16 \\
\cline { 1 - 3 } $\mathrm{CHX}$ & $1.29^{\mathrm{C}}$ & 1.07 & \\
\hline
\end{tabular}

*: Significant at $\mathrm{P} \leq 0.05$, Different superscripts in the same column are statistically significantly different 
Table 4:-Descriptive statistics and results of Wilcoxon signed-rank test for comparison between $\log _{10} \mathrm{CFU}$ counts at different time periods within each group

\begin{tabular}{|l|c|c|c|c|c|}
\hline \multirow{2}{*}{ Group } & \multicolumn{2}{|c|}{1 week } & \multicolumn{2}{|c|}{2 weeks } & \multirow{2}{*}{$P$-value } \\
\cline { 2 - 5 } & Mean & SD & Mean & SD & \\
\hline Saline & 5.28 & 0.08 & 5.26 & 0.06 & 0.674 \\
\hline Propolis & 4.21 & 0.10 & 3.31 & 0.20 & $0.012^{*}$ \\
\hline $\mathrm{Ca}(\mathrm{OH}) 2$ & 4.29 & 0.09 & 3.52 & 0.16 & $0.012^{*}$ \\
\hline $\mathrm{CHX}$ & 2.66 & 0.12 & 1.29 & 1.07 & $0.012^{*}$ \\
\hline
\end{tabular}

*: Significant at $\mathrm{P} \leq 0.05$

Table 5:-Descriptive statistics and results of Kruskal-Wallis test for comparison between percentage reduction in bacterial counts within each group after 2 weeks

\begin{tabular}{|l|c|c|c|}
\hline Group & Mean \% & SD & $P$-value \\
\cline { 1 - 3 } Saline & $0.43^{\mathrm{C}}$ & 1.71 & \multirow{2}{*}{$<0.001^{*}$} \\
\hline Propolis & $21.4^{\mathrm{B}}$ & 3.6 & \multirow{2}{*}{} \\
\hline $\mathrm{Ca}(\mathrm{OH}) 2$ & $17.9^{\mathrm{B}}$ & 3.9 \\
\hline $\mathrm{CHX}$ & $51.8^{\mathrm{A}}$ & 40.2 & \\
\hline
\end{tabular}

*: Significant at $\mathrm{P} \leq 0.05$, Different superscripts in the same column are statistically significantly different

\section{References:-}

1. Kandaswamy D, Venkateshbabu N, Gogulnath D, Kindo A J. Dentinal tubule disinfection with $2 \%$ Chlorhexidine gel, propolis, morinda citrifolia juice, $2 \%$ povidone iodine, and calcium hydroxide. Int Endod J. 2010;43(5):419-23.

2. Borzini L, Condò R, De Dominicis P, Casaglia A, Cerroni L. Root Canal Irrigation: Chemical Agents and Plant Extracts Against Enterococcus faecalis. Open Dent J. 2016;10:692-703.

3. Mohammadi Z. Chlorhexidine gluconate, its properties and applications in endodontics. Int Endod J. $2008 ; 2(4), 113-25$.

4. Jahromi MZ, Toubayani H, Rezaei M. Propolis: A new Alternative for Root Canal Disinfection. Iran Endod J. 2012;7:127-33.

5. Mohammadi Z, Shalavi S, Yazdizadeh M. Antimicrobial Activity of Calcium Hydroxide in Endodontics: A Review. Chonnam Med J. 2012;48:133-140

6. Jahromi MZ, Ranjbarian P, Shiravi S. Cytotoxicity Evaluation of Iranian Propolis and Calcium Hydroxide on Dental Pulp Fibroblasts. J Dent Res Dent Clin Dent Prospects. 2014;8:130-133.

7. Bhandari S, Ashwini TS, Patil CR. An in Vitro Evaluation of Antimicrobial Efficacy of $2 \%$ Chlorhexidine Gel, Propolis and Calcium Hydroxide Against Enterococcus faecalis in Human Root Dentin. J Clin Diagn Res. 2014;8:60-63.

8. Parolia A, Thomas MS, Kundabala M, Mohan M. Propolis and its potential uses in oral health. Int J Med Med Sci. 2010;2:210-15.

9. Martos MV, Navajas YR, Lopez JF, Alvarez JAP. Functional Properties of Honey, Propolis, and Royal Jelly. J Food Sci. 2008;73(9).

10. Rezende GPSR, Costa LRRS, Pimenta FC, Baroni DA. In Vitro Antimicrobial Activity of Endodontic Pastes with Propolis Extracts and Calcium Hydroxide: A Preliminary Study. Braz Dent J: 2008;19(4):301-305.

11. Parolia A, Kundabala M, Rao N, Acharya S, Agrawal P, Mohan M, et al. A comparative histological analysis of human pulp following direct pulp capping with Propolis, mineral trioxide aggregate and Dycal. Aust Dent J. 2010;55(1):59-64.

12. Pimenta HC, Violante IMP, Musis CR, Borges AH, Aranha AMF. In vitro effectiveness of Brazilian brown propolis against Enterococcus faecalis. Braz Oral Res. 2015;29(1):1-6.

13. Akca AE, Akca G, Topcu FT, Macit E, Pikdoken L, Ozgen IS. The Comparative Evaluation of the Antimicrobial Effect of Propolis with Chlorhexidine against Oral Pathogens: An in Vitro Study. BioMed Research International. 2016;1-8.

14. Gomes B, Vianna M, Zaia A, Almeida J, Flho F, Ferraz C. Chlorhexidine in Endodontics. Braz Dent J. 2013; 24(2):89-102. 
15. Pavaskar R, Ataide IN, Chalakkal P, Pinto MJ, Fernandes KS, Keny RV, Kamatb A. An In Vitro Study Comparing the Intracanal Effectiveness of Calcium Hydroxide- and Linezolid-based Medicaments against Enterococcus faecalis. J Endod. 2012;38(1):95-100.

16. Lima RKP, Guerreiro-Tanomaru JM, Faria-Ju' nior NB, Tanomaru-Filho M. Effectiveness of calcium hydroxide- based intracanal medicaments against Enterococcus faecalis. Int Endod J. 2012;45(4): 311-316.

17. Tabrizizadeh M, rasti M, Ayatollahi F, Mossedegh MH, Zandi H, Dehghan F, Mousavi Z. Antimicrobial Activity of Calcium Hydroxide and Betamethasone on Enterococcus faecalis; An in vitro Assessment. Iran Endod J. 2015;10(3):184-187.

18. Wang CS, Arnold RR, Trope M, Teixeira FB. Clinical Efficiency of $2 \%$ Chlorhexidine Gel in Reducing Intracanal Bacteria. J Endod. 2007;33(11):1283-89.

19. Paquette L, Legner M, Fillery ED, Friedman S. Antibacterial Efficacy of Chlorhexidine Gluconate Intracanal Medication in Vivo. J Endod. 2007;35(7):788-95.

20. Ballal V, Kundabala M, Acharya S, Ballal M. Antimicrobial action of calcium hydroxide, chlorhexidine and their combination on endodontic pathogens. Aust Dent J. 2007;52(2):118-21.

21. Evans M, Baumgartner J, Khemaleelakul S, Xia T. Efficacy of Calcium Hydroxide: Chlorhexidine Paste as an Intracanal Medication in Bovine Dentin. J Endod. 2003;29(5):338-9.

22. Gomes BPFA, Souza SFC, Ferraz CCR, Teixeira FB, Zaia AA, Valdrighi L, et al. Effectiveness of $2 \%$ chlorhexidine gel and calcium hydroxide against Enterococcus faecalis in bovine root dentine in vitro. Int Endod J. 2003;36(4):267-75.

23. Almyroudi A, Mackenzie D, Mchugh S, Saunders W. The Effectiveness of Various Disinfectants Used as Endodontic Intracanal Medications: An In Vitro Study. J Endod. 2002;28(3):163-7.

24. Stuart C, Schwartz S, Beeson T, Owatz C. Enterococcus faecalis: Its Role in Root Canal Treatment Failure and Current Concepts in Retreatment. J Endod. 2006;32(2):93-98.

25. Gijo J, Kumar PK, Gopal SS, Kumari S, Reddy BK. Enterococcus faecalis, a nightmare to endodontist: A systematic review. Afr J Microbiol Res. 2015;9(13):898-908.

26. Bhardwaj SB. Role of Enterococci faecalis in failure of Endodontic treatment. Int J Curr Microbiol App Sci. 2013;2(8):272-77

27. Mallic R, Mohanty S, Behera S, Sarangi P, Nanda S, Satapathy SK. Enterococcus faecalis: A resistant microbe in endodontics. Int J Contemp Dent Med Rev. 2014;1-2.

28. Hazan R, Que Y, Maura D, Rahme LG. A method for high throughput determination of viable bacteria cell counts in 96-well plates. BMC Microbiol. 2012;12(1):1-7.

29. Bapat P, Nandy SK, Wangikar P, Venkatesh KV: Quantification of metabolically active biomass using Methylene Blue dye Reduction Test (MBRT): measurement of CFU in about 200 s. J Microbiol Methods. 2006;65:107-16.

30. Miller JH, Determination of viable cell counts: bacterial growth curves. In Experiments in Molecular Genetics. Edited by Miller JH. New York: Cold Spring Harbor. 1972;31-36. 